Matematikai Közlemények

IX. kötet, 2021

doi:10.20312/dim.2021.01

\title{
Majdnem szabályos sokszöglapok által határolt konvex poliéderek számítógépes modellezése
}

\author{
Talata István \\ Óbudai Egyetem, \\ Ybl Miklós Építéstudományi Kar, Budapest, \\ és BGE Külkereskedelmi Kar, Budapest \\ talata.istvan@ybl.uni-obuda.hu
}

\begin{abstract}
ÖSSZEFOGLALÓ. Léteznek olyan konvex poliéderek (ún. ál-Johnson-poliéderek), melyeknek mindegyik sokszöglapja szabályos sokszög vagy annak egy jó közelítése valamilyen értelemben, és esetleg nem is (vagy alig) észrevehető ezeken a poliédereken, hogy a lapjaik között van nem pontosan szabályos sokszög, miközben megmutatható, hogy nem létezik olyan konvex poliéder, melynek ugyanaz a laphálója, és minden lapja szabályos sokszög. Bemutatjuk, hogyan modellezhetők az ilyen poliéderek geometriai módszerek felhasználásával, azaz valamely geometriai szoftverrel megvalósított térbeli geometriai szerkesztésekkel.
\end{abstract}

ABSTRACT. The near-miss Johnson solids are such convex polyhedra whose faces are regular polygons or polygons whose shape is close to a regular polygon in some sense, and in some cases, it can not be (or it can only be slightly) observed that not all faces are regular polygons - however there is no such convex polyhedron with the same face net having only regular polygons as faces. We show how to model such polyhedron using only geometric methods, that is, how to create a virtual model of that polyhedron using space geometric construction steps with a geometry software.

\section{Bevezetés}

Olyan konvex poliédereknek a modellezésével fogunk foglalkozni, melyek lapjainak alakja szabályos sokszög vagy annak egy jó közelítése, de nincs olyan konvex poliéder ugyanolyan laphálóval, melynek minden lapja szabályos sokszög lenne. (Ezért egy ilyen poliéder nem lehet egy csupán szabályos sokszög alakú lapok által határolt poliédernek egy kissé deformált változata, ugyanazzal a laphálóval.) És emiatt biztos van olyan lapja a vizsgált poliédernek, amely nem pontosan szabályos sokszög, még ha ahhoz közeli is az alakja. Geometriai modellezést fogunk alkalmazni.

A következőkben röviden áttekintünk néhány kapcsolódó témakört, és összefoglaljuk a számunkra fontos jellemzőit a geometriai modellezésnek, a szerkeszthetőségnek, ill. paraméteres modellezésnek, és a szabályos sokszöglapokkal határolt konvex poliéderek esetében használható geometriai modellezési módszereket. Mindezek után, a következő fejezetben arra keresünk választ, hogyan definiálhatjuk a majdnem szabályos sokszöglapokat, majd utána elöször megvizsgáljuk, hogy néhány nevezetes poliéderosztály elemei ilyen lapokból állnak-e, majd általánosságban foglalkozunk ilyen lapok által határolt konvex

KULCSSZAVAK. Ál-Johnson-poliéder, dinamikus geometria, számítógépes modellezés.

KEYWORDS. Near-miss Johnson solid, dynamic geometry, computer modelling. 
poliéderekkel, később pedig konkrét példákat mutatunk be, felvázolva a szerkesztési módszereket az egyes esetekben. Végül összefoglaljuk a tapasztalatainkat.

\subsection{Geometriai modellezés}

Nagyon sokféle 3-dimenziós poliéder számítógépes modellezése történhet csupán geometriai módszerekkel. Ekkor egy geometriai szoftver térbeli szerkesztési müveleteit használjuk a poliédermodell pontos vagy közelítő (adott hibahatáron belüli pontosságú) megszerkesztéséhez.

Geometriai módszerekkel történő modellezés esetén egyszerű alakzatokból kiindulva készítünk összetett modellt, új alakzatok vagy segédalakzatok segítségével (pl. szerkesztőegyenesek, szakaszok, körök, síkok, sokszöglapok, gömbök felhasználásával), és geometriai transzformációk (pl. forgatás, eltolás, tükrözés) alkalmazásával. Ilyenkor az egymásra épülő szerkesztési lépések garantálják a poliéderlapok megfelelő illeszkedését. A poliéder esetleges szimmetriáit kihasználva forgatásokkal és tükrözésekkel fejezhető be a modell, garantálva a végső modell megfelelö szimmetriáit.

A geometriai módszerek használata amellett, hogy elegáns, matematikai képletek bevitelétől mentes szerkesztést tesz lehetővé, fejleszti a modellező térlátását és egyéb téri képességeit is, így a konkrét modellezett poliéder egyes geometriai és kombinatorikai tulajdonságait ( $\mathrm{pl}$. szimmetriákat, az egyes lapok egymáshoz viszonyított helyzetét is könnyebben felismerheti a modellező, már a modellezési eljárás során megismerve ezeket).

\subsection{Szerkeszthetőség és paraméteres modellezés}

A szokásos szoftveres térbeli szerkesztési lépések visszavezethetők gömb, sík, térbeli egyenes, térbeli kör alakzatoknak a felvételére és ilyen alakzatok metszéspontjainak a megszerkesztésére, amely müveletek a síkbeli körzővel-vonalzóval történő szerkesztési lépésekhez hasonlóan úgy bővítik a megszerkesztett pontok halmazát, hogy azok koordinátái megfelelő másodfokú testbővítések egymás utáni alkalmazásával mindig megkaphatók. Ezért ha egy poliéder bizonyos csúcspárjainak a távolságának a racionális számok feletti minimálpolinomja nem kettőhatvány, akkor az a poliéder nem szerkeszthető meg csupán racionális koordinátájú pontokból kiindulva (ld. [5]).

Dinamikus geometriai szoftverekkel történő szerkesztések esetén azonban paraméteres poliédermodelleket is tudunk készíteni, azaz a modellezés során később folytonosan változtatható paraméterértékeket (tipikusan geometriai jelentéssel bíró, pl. szög nagyságát vagy szakasz hosszát megadó értékeket) is felhasználhatunk - vagy ennek megfelelő változtatható alakzatokat helyezhetünk el a modellben, pl. pontot körön vagy szakaszon mozgathatunk, amely mozgás szög, ill. távolság változásának feleltethető meg. Így bizonyos nemszerkeszthető poliéderek tetszőleges pontossággal modellezhetők, amennyiben készíthető olyan paraméteres poliédermodell, amelynek a paraméterértékeinek a megfelelö beállításaival a kívánt poliéderközelítés elérhető. Egyetlen paraméter használata esetén, folytonossági meggondolások alapján elég egyszerü a megfelelő paraméterérték megtalálása.

\subsection{Számítógépes modellezés szabályos sokszöglapok által határolt konvex poliéderek esetén}

Most áttekintjük, hogy a szabályos sokszöglapok által határolt konvex poliéderek hogyan modellezhetők geometriai módszerekkel. A szabályos testek (hasonlóság erejéig $5 \mathrm{db}$ ilyen test van) mind szerkeszthetők, és persze a szabályos sokszöglapokkal rendelkező egyenes hasábok és antiprizmák végtelen családjai is szerkeszthetők. Az arkhimédészi, félig szabályos testek $(13 \mathrm{db})$ között azonban már található két nemszerkeszthető test: a pisze kocka és a pisze dodekaéder. A fennmaradó, szabályos sokszöglapok által határolt konvex poliéderek a 
Johnson-poliéderek (ezekböl 92 db van), közülük 85 db könnyen szerkeszthetö, azonban van 7db olyan Johnson-poliéder, amely nem szerkeszthető (vagy valószínüleg nem szerkeszthetö), ezek a J84-J90 sorszámú poliéderek. Azonban a fentebb említett összesen 9 nemszerkeszthető poliéder mindegyikének elkészíthető a virtuális modellje tetszőleges pontossággal, alkalmasan választott 1-paraméteres poliédermodell készítésével, majd a paraméter megfelelö értékre történő beállításával. Mindez azért lehetséges, mert az itt említett poliéderosztályok mindegyikének az elemei rendelkeznek több-kevesebb szimmetriával - enélkül lehet hogy csak legalább 2 paraméteres poliédermodell alkalmazásával tudnánk valamelyik poliédert modellezni, márpedig ezek esetében a paraméterértékek megfelelő beállítása sokkal nehezebben oldható csak meg.

Tehát a szabályos sokszöglapokkal határolt konvex poliéderek többsége szerkeszthető, a fennmaradó 9 test pedig megfelelő 1-paraméteres modellek felhasználásával tetszöleges pontossággal modellezhető egyszerüen, dinamikus geometriai szoftverekkel.

A szabályos testek megszerkeszthetők: elég egyetlen testszögletüket megszerkeszteni, pl. lapjaik felhajtásával. A szabályos hasábok és antiprizmák esetére is müködik ez a módszer. Az arkhimédeszi testek többségénél is ez a helyzet, de azok szabályos testekböl másképp is elöállíthatók: szeléssel, lapok eltolásával, lapok forgatva eltolásával. A legtöbb Johnsonpoliéder előállítható arkhimédészi testekből, hasábokból és antiprizmákból geometriai alapmüveletekkel (csúcsok által meghatározott síkkal való szelés, közös lap mentén egyesítés).

\section{Majdnem szabályos sokszöglapok}

Most nézzük, hogyan definiálható precízen, hogy majdnem szabályos sokszögek alkotják egy poliéder lapjait? A lapok alakjának eltérését mérjük majd az ugyanannyi csúcsú szabályos sokszög alakjától. A szakirodalomban van olyan szerző, aki egy poliéderre az összes lapnak az ott áhított egységnyi élhosszú szabályos sokszögektől való eltéréseit úgy méri, hogy összeadja az élhosszak 1-től való eltéréseinek az abszolút értékét az összes élre, és a lapok szögei esetén az ugyanannyi csúcsú szabályos sokszög szögértékeitől való eltérések abszolút értékeinek az összegét veszi. Így a poliéderre két mennyiséget kapunk, az élek abszolút eltéréseinek az összegét és a szögek abszolút eltéréseinek az összegét. Egy másik szerző pedig az egész poliéderre csupán a leghosszabb és legrövidebb él arányát tekinti, ezt az egy mérőszámot használja mérőszámként.

Szerintünk a lapoknak a szabályos sokszögtől való legnagyobb eltérését kell vizsgálni, ez mutatja meg, hogy mennyire észrevehető hogy nem szabályos sokszög alakú egy lap. Úgy gondoljuk, hogy a szabályosságot a szemünkkel lokálisan, laponként ellenőrizzük, méghozzá szimmetriaként, a lap élhosszainak ill. a lap szögeinek az egyenlőségét tesztelve szemünkkel. Ezért vegyük egy lap leghosszabb és legrövidebb oldalainak az arányát (ez legalább 1, mivel a számláló legalább akkora, mint a nevező egy ilyen típusú törtben), valamint a lap legnagyobb és legkisebb szögének a különbségét is számítsuk ki (ez pedig mindig nemnegatív mennyiség, mert a legnagyobb szögböl vonjuk ki a legkisebbet). Minden lapra számítsuk ki ezt a két mennyiséget, majd ezek maximumát vegyük mindkét esetben. Jelölje $E R(P)$ az egyes lapokhoz tartozó legnagyobb élarányok maximumát, és jelölje $A D(P)$ az egyes lapokhoz tartozó legnagyobb szögkülönbségek maximumát, egy $\mathrm{P}$ konvex poliéder esetén (ER=edge_ratio, $\mathrm{AD}=$ angle_difference). Ha az $E R(P)$ legfeljebb $1+\varepsilon$ valamely $\varepsilon>0$ esetén, és $\bar{A} D(P)$ legfeljebb $\delta$ valamely $\delta>0$ esetén, akkor azt mondjuk, hogy a lap alakja az $(\varepsilon, \delta)$ hibahatárokon belül közeli a szabályos $n$-szöghöz, ill. a lap az $(\varepsilon, \delta)$-hibahatárokon belül szabályos sokszöglap. Közel szabályos sokszöglapnak nevezzünk egy poliéderlapot, ha az teljesíti a következő feltételt: 
1) A poliéder minden lapja legfeljebb az $(\varepsilon, \delta)$-hibahatárokon belül közeli egy olyan szabályos sokszöghöz, melynek ugyanannyi csúcsa van, mint a lapnak.

Ha az $\varepsilon$ és $\delta$ mennyiségeket megfelelően kicsi pozitív értéknek választjuk, akkor a szemünk tényleg nem látja a különbséget a szabályos sokszög és a töle $(\varepsilon, \delta)$-hibahatárokon belül közeli sokszög között.

A látványon túlmenően van néhány egyszerü szabály, amelynek fenn kell állnia, ha egy konvex poliédernek mindegyik lapja szabályos sokszög:

2) A lapok egy csúcsnál fekvö szögeinek összege $360^{\circ}$-nál kisebb legyen mindegyik csúcs esetén.

3) Ha két sokszöglap közös éllel csatlakozik egymáshoz, akkor szimmetria miatt, a két sokszöglapból a közös él egyik csúcsába befutó másik két él egymással bezárt szöge megegyezik a közös él másik csúcsába befutó másik két él egymással bezárt szögével.

Az is elvárás lehet, hogy szabályos sokszöglaphoz közeli alakú lapok esetén egy poliéder megfeleljen ezeknek a szabályoknak akkor is, ha úgy számolunk az esetében, mintha minden lapja szabályos sokszöglap lenne, hogy legalább az ilyen egyszerü lokális szabályoknak megfeleljen a laphálója akár szabályos sokszögekkel is (ezeknél az egyszerü lokális vizsgálatoknál még ne derüljön ki, hogy a poliéder laphálója esetleg nem realizálható szabályos sokszöglapokkal).

A fenti 3 szabályt nevezhetjük 1. feltételnek, 2. feltételnek, ill. 3. feltételnek, melyeknek fenn kell állniuk, hogy a poliéder jelölt maradhasson arra, hagy szabályos sokszöglapok által határolt (az 1. feltétel bármely pozitív $(\varepsilon, \delta)$-hibahatárokra fennáll ilyenkor). Ami nem világos, hogy milyen nagynak választhatjuk az $\varepsilon$ és $\delta$ értékeket, hogy a szemünkkel már ne érzékeljük az eltérést a szabályos sokszögtől, ha a sokszög $(\varepsilon, \delta)$-hibahatárokon belül közeli egy szabályos sokszöghöz.

A 2., ill. 3. számú feltételek következményei:

2b) Mindegyik csúcsnál legfeljebb 5 lap találkozik.

2c) 3 db hatszöglap nem találkozhat egy csúcsban.

2d) 2 db hatszöglap és 2 db háromszöglap (összesen 4 lap) nem találkozhat egy csúcsban.

3b) Ha két szabályos sokszöglap közös éllel csatlakozik egymáshoz, és a közös él egyik csúcsánál csak három sokszöglap találkozik, akkor

- vagy csak három sokszöglap találkozik a közös él másik csúcsánál, és a közös él két csúcsánál található harmadik sokszöglapok egybevágóak (azaz oldalszámuk megegyezik),

- vagy a közös él másik csúcsánál legalább négy sokszöglap találkozik, melyek közül az emlitett közös élre nem illeszkedö legalább két sokszöglap szögeinek összege ennél a másik csúcsnál nagyobb, mint az él egyik csúcsánál található harmadik sokszöglap szöge.

\section{Néhány nevezetes, majdnem szabályos sokszöglapokkal rendelkező poliéderosztály}

Vannak olyan nevezetes poliéderosztályok, melyek elemei jelöltek lehetnek majdnem szabályos sokszöglapok által határolt konvex poliéderekre. Egyik ilyen a geodézikus poliéderek családja, a másik a Goldberg-poliéderek családja (ld. [4]). Egy geodézikus poliéder csúcsai egy gömbfelületen vannak, csak háromszöglapjai vannak, és ha elég kis háromszögekről van szó (ami nagy csúcsszám esetén teljesül), akkor előfordulhat, hogy sok háromszöglapjának az 
alakja elég közeli a szabályos háromszögéhez. De van mindig valahány (legalább 4) csúcsa, ahol legfeljebb 5-5 db háromszöglap találkozik, így ott a kis háromszöglapok csúcsai nem lehetnek $60^{\circ}$-hoz közeliek (mivel a csúcsban találkozó szögek összege $360^{\circ}$-hoz közeli nagy csúcsszám esetén). Így mégse igazán jó jelölt ez a poliédercsalád, pláne mert a 2 . feltételt sem teljesítik az ilyen poliéderek szabályos háromszöglapok szögeivel számolva, ugyanis mindig van olyan csúcsa, ahol 6 db háromszöglap találkozik (és nagy csúcsszám esetén az ilyen csúcsok vannak túlnyomó többségben, mondhatjuk, hogy majdnem minden csúcsa ilyen).
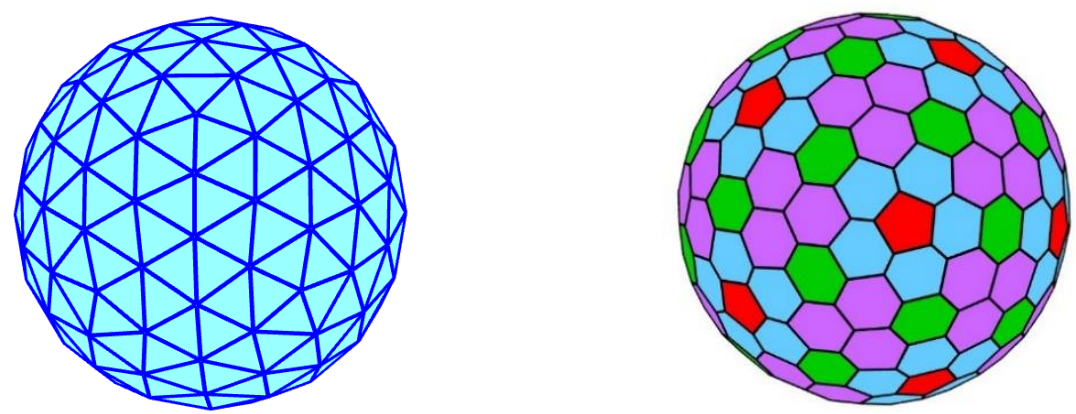

1. ábra. Geodézikus dodekaéder L2 és egy Goldberg-poliéder (duális ikozaéder L3)

A Goldberg-poliéderek az ikozaéderes szimmetriájú geodézikus poliéderek duálisai, 12 szabályos ötszöglapjuk van, a többi lap hatszöglap, és mindegyik lap érinti a beírt gömböt. De így amely csúcsnál az ötszöglaphoz csatlakoznak a hatszöglapok, az ott találkozó lapok csúcsszögeinek összege $360^{\circ}$-hoz kellene, hogy közel legyen (ez nagy csúcsszám esetén teljesül), azonban az ötszöglap $108^{\circ}$-os szöge miatt a másik két hatszöglap csúcsszöge annál a csúcsnál nem lehet közel $120^{\circ}$-hoz, így nem lehet közel az alakjuk szabályos hatszöghöz. És itt is fennáll, hogy a 2. feltétel nem teljesül, ha a lapoknál szabályos sokszögek szögeivel számolunk, mivel sok csúcsban három hatszöglap találkozik, melyeknél a szögösszeg $360^{\circ}$ lenne.

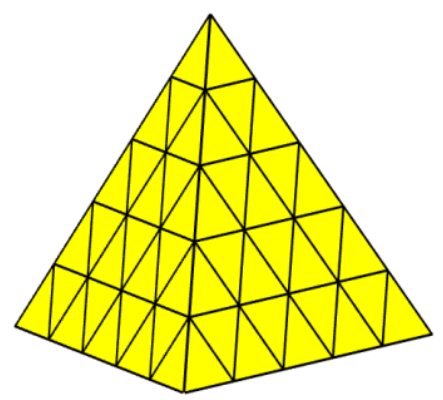

2. ábra. Szabályos tetraéder lapjainak egy rácsfelosztása

Végül, ha veszünk egy olyan konvex poliédert, melynek lapjai feloszthatók rácsfelosztással akármilyen sok szabályos háromszögre vagy négyzetre, akkor kicsit elmozdíthatjuk a felosztás csúcsait úgy, hogy egy konvex poliéder csúcsai legyenek, és a poliéder laphálóját a lapok rácsfelosztásai adják. A szabályos tetraéder vagy a kocka ilyen poliéderek, hiszen bármilyen nagy finomságú szabályos háromszögrácsos ill. négyzetrácsos felosztást lehet rárajzolni a háromszöglapjaikra ill. négyzetlapjaikra, de jó pár más poliéder is létezik ilyen tulajdonsággal, pl. a csak szabályos háromszöglapokkal vagy négyzetlapokkal rendelkezö poliéderek ilyenek, de elöfordulhat szabályos hatszöglap, paralelogramma alakú lap (amely $2 \mathrm{db}$ szabályos háromszögre osztható fel), ill. trapéz alakú lap (amely $3 \mathrm{db}$ szabályos háromszögre osztható fel) az ilyen tulajdonságú poliéderek lapjai között. A rácsfelosztás háromszögei ill. négyszögei kissé 
eldeformálódnak a csúcsok elmozdítása során, de azért ilyenkor az megvalósítható, hogy a négyszögek megmaradjanak síkbeli négyszögeknek, és bár már nem lesznek szabályos sokszögek a rácsfelosztásból lett lapok, de tetszőlegesen közeliek lehetnek a szabályos sokszögekhez a lapok a csúcsok elég kismértékű elmozdítása esetén. Így bármely adott $\varepsilon>0$ és $\delta>0$ esetén is végtelen sok olyan poliéder adódik, amely megfelel az 1 . feltételnek - de a 2. feltételnek persze már nem fog megfelelni, ha a lapoknál szabályos sokszögek szögeivel számolunk, mivel akkor sok csúcsban $360^{\circ}$ jön ki szögösszegnek.

\section{4. Ál-Johnson-poliéderek}

Vajon mi a helyzet, ha nem pontosan szabályosak a poliéder lapjai? Elöször is egy ehhez kapcsolódó tételt említünk: a Cauchy-tétel kimondja, hogy ha egy konvex poliéder lapjainak alakját merevnek tekintjük, és a lapok közös éleit csuklóknak, akkor a poliéder merev, azaz nem deformálható át másféle alakúvá. Söt, ennél több is igaz: ha adott a sokszöglapok alakja (egybevágóság erejéig) valamint adott a lapháló, amely meghatározza, hogyan csatlakoznak egymáshoz a lapok, akkor legfeljebb egy konvex poliéder létezik, melynek a sokszöglapjai és a hozzá tartozó laphálója megegyeznek ezekkel.

Azt, hogy 92 Johnson-poliéder létezik, még Johnson sejtette meg 1966-ban (ld. [2]), és bár korábban el is ért néhány részeredményt a sejtése igazolásának az irányában (pl. Grünbaummal közös cikkében igazolta 1964-ben, hogy csak véges sok olyan konvex poliéder létezik, melynek minden lapja szabályos sokszög, ld. [1]), de a sejtését végül is Zalgaller bizonyította be 1967ben (ld. [6]). A véges sok eset vizsgálatakor kiderült, hogy jó pár esetben azért létezik olyan konvex poliéder, melynek mindegyik lapjának az alakja igen közeli egy szabályos sokszöghöz.

Ál-Johnson-poliédernek nevezzük az olyan konvex poliédert, melynek nem minden lapja szabályos sokszög, de a 2 . fejezet 1 . feltétele teljesül valamely adott $\varepsilon$ és $\delta$ pozitív számokra (angolul: near-miss Johnson solid). Azaz egy ál-Johnson-poliéder lapjai az $(\varepsilon, \delta)$-hibahatárokon belül szabályos sokszögek, de legalább 1 lapja nem szabályos sokszög (ld. [3]). Mivel minden poliéder ál-Johnson-poliéder megfelelően nagy $\varepsilon$ és $\delta$ számokra, ezért $(E R(P)-1)$ és $E D(P)$ értékei (ha $P$ jelöli a poliédert) - a 2 . fejezetben bevezetett jelölésekkel - adják meg a legkisebb $\varepsilon$ és $\delta$ értékeket, melyekre a poliéder még ál-Johnsonpoliéder.

Nevezzük 1., 2., ill. 3. típusú ál-Johnson-poliédernek az olyan konvex poliédert, melyre az 1., az 1. és 2., ill. az 1., 2. és 3. feltételek teljesülnek (ha a 2, és 3. feltételben úgy számolunk a szögekkel, mintha a poliéder minden lapja szabályos sokszöglap lenne). Az 1. feltétel adott $\varepsilon$ és $\delta$ pozitív számok esetén teljesül, itt olyan értékekre gondolunk, amelyek esetén a sokszög már látszólag szabályos, de azért a lehető legnagyobb ilyen értékeket szeretnénk választani, hogy legyen egyáltalán a feltételeknek megfelelő poliéder, akár minél több is. Az, hogy az $\varepsilon$ és $\delta$ pozitív számokra mely értékek a megfelelő választás, még további vizsgálatok tárgya kell, hogy legyen.

Ha a poliédernek csak a háromszöglapjai nem szabályosak, akkor $\delta$-tól eltekinthetünk, mivel egy háromszög oldalhosszai már meghatározzák annak alakját is, így azt is, hogy menyire közeli az alakja egy szabályos háromszöghöz. Ekkor $\varepsilon=0,02$ már jó választásnak tünik, ld. az 5. fejezet 2. példáját.

Érdekesség, hogy ha egy ál-Johnson poliéder tényleg látszólag szabályos sokszöglapokkal rendelkezik, akkor jó esély van rá, hogy pl. papírmodellt vagy pálcikamodellt (amely megfelelő lapátlókhoz tartozó pálcikák berakásával már merev lesz) tudunk készíteni belőle, mivel a fizikai modellkészítés során fellépő pontatlanságok elfedik a kis illeszkedési pontatlanságokat.

A 3. fejezet utolsó poliéderosztálya példa arra, hogy végtelen sok 1. típusú ál-Johnsonpoliéder létezik, míg a 3. típusú ál-Johnson-poliéderekből valószínűleg már csak véges sok van 
(megfelelően kis $\varepsilon$ és $\delta$ pozitív számok esetén, amik azért garantálják, hogy ne üres halmaz legyen ekkor az ál-Johnson-poliéderek családja), mivel Grünbaum és Johnson fentebb említett végességi bizonyítása is a 2 . és 3 . feltételen alapszik.

Megfelelő müveletek megengedésével persze minden poliéderről eldönthető (akár geometriai módszerekkel is), hogy Johnson-poliéder-e vagy sem - mert pl. egy olyan szabályos sokszöget rajzolva egy tetszőleges lap síkjában, amelynek egyik oldala a poliéder egyik éle, és a sokszög a lap irányában fekszik ugyanannyi csúccsal, mint a lap csúcsainak száma, ellenőrizhető, hogy az a szabályos sokszög megegyezik-e a lappal.

Az ál-Johnson-poliéderek egy-egy típusának sokszor többféle megvalósítása is van, mivel elöállíthatók ugyanolyan laphálójú, de alakjukban csak kicsit különböző poliéderek. Van, amikor arra törekednek egy konstrukcióban, hogy minél több szabályos sokszöglapja legyen az ál-Johnson-poliédernek, de van, hogy inkább arra, hogy minden lapja minél közelebbi alakú legyen egy szabályos sokszöghöz, még ha ennek az is az ára, hogy egyik lap sem lesz pontosan szabályos sokszög. Általában minél több szabályos sokszöglapja van egy poliédernek, annál egyszerübb a modellezése.

Az ál-Johnson-poliéderek nem szabályos sokszöglapjai gyakran a lehető legkisebb oldalszámú lapoknál (háromszöglapok, négyszöglapok esetében) vannak. Ilyenkor a szabályos sokszöglapok és a lapháló szimmetriái (amelyek tipikusan megvalósulnak metrikus szimmetriaként is) alapján sokszor már megszerkeszthető a poliéder. Sokszor azért is van értelme ilyen poliédermodell készítésének, mert így a poliéder felületének a kisebb része lesz nem szabályos, ugyanis ugyanakkora élhossz esetén a szabályos n-szög területe nö, ha $n$ növekszik.

Ál-Johnson-poliéderek számítógépes modellezésekor vigyázni kell, hogy ne automatikusan tekintsük a poliéder bármelyik lapját szabályos sokszögként megszerkeszthetőnek, mert nem megfelelö választás esetén nem záródó poliéderfelületet kapunk.

Ál-Johnson-poliédereknek egy gyakori előállítási módja: az arkhimédészi ill. Johnsonpoliéderek szerkesztésekor használható szerkesztési módszerek alkalmazása más esetekre: lapok szelése, lapok kifelé eltolása, lapok piszésítése (eltolva forgatása kifelé). Ilyenkor tipikusan már nem mindegyik újonnan keletkezett lap lesz szabályos sokszög, de törekszünk rá hogy minél kevesebb nem szabályos sokszöglap legyen, azért aránylag nem messze eső alakkal a szabályos sokszögtől, vagy minél kisebbek legyenek a keletkező nem szabályos lapok (pl. háromszögek, négyszögek, mivel oldalszámmal nö a terület is). Illetve, annak is van elönye, ha páratlan oldalú sokszög lesz a nem szabályos (pl. ötszög), mert a páros oldalúaknál talán könnyebben észrevehető, ha elromlik valahol a szimmetria, mondjuk a centrálszimmetria, és ezért bizonyos szemközti oldalak nem lesznek párhuzamosak. Szelésre gyakran kiindulópont egy katalán test (ez az arkhimédészi test duálisa), mert annak a csúcsalakzatai szabályosak, így megfelelő szelősíkok esetén szabályos sokszöglapok keletkeznek a szelések helyén, és akkor már csak arra kell ügyelni, hogy a többi keletkező lap közel szabályos sokszög alakú legyen.

\section{Példák ál-Johnson-poliéderek számítógépes modellezésére}

A következőkben néhány ál-Johnson-poliéder esetében megvizsgáljuk, hogyan lehet elkészíteni a számítógépes modelljüket (az ál-Johnson poliédereknek egy közel sem teljes listája megtalálható a [3]-as hivatkozásban).

1. példa. Csonkolt kettős gúla - itt két modellezési lehetőség van. Az egyik, ha pontosan négyzetlapokat szerkesztünk, akkor 1 paraméter marad arra, hogy a csonkolt lapok minél jobban hasonlítsanak a szabályos ötszöglapokra. A másik esetben kétparaméteres a probléma: ha csak négyzethez közeli lapokat készítünk, ekkor olyan paraméterértékeket keresünk, hogy a négyszöglapok a négyzethez, az ötszöglapok a szabályos ötszöghöz legyenek a lehető legközelebb (az ötszöglapok nem lehetnek szabályos ötszögek, mert akkor a négyszögek nem 
lennének síklapok). Ez a poliéder 2. típusú ál-Johnson-poliéder, mivel a 3. feltétel nem teljesül rá, de az ötszöglapjain könnyen látható, hogy nem szabályosak, csak képzeletben húzzuk be az átlóit, látszik, hogy nem egyformán osztják ketté az ötszöglapot.
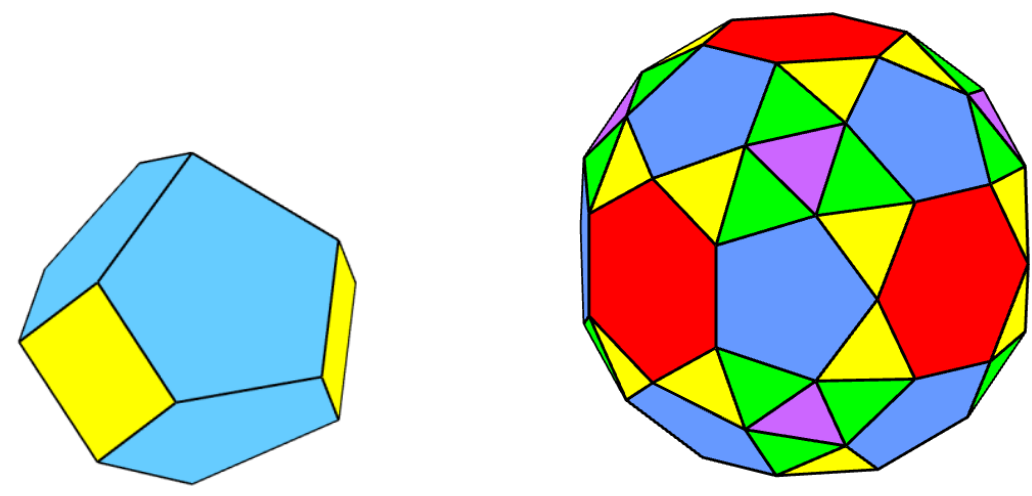

3. ábra. Az 1. példa és a 2. példa ál-Johnson-poliéderei

2. példa. Ez a poliéder a pentahexagonális piritoheptakontatetrahedron névre hallgat (Mason Green fedezte fel 2006-ban). A lapháló szimmetriáit szeretnénk metrikus szimmetriaként is elöállítani. A $6 \mathrm{db}$ hatszöglap átellenes sokszögpárokat alkot, ezeknek a pároknak közös forgástengelyük van (180 fokos forgásszimmetria miatt). A 3 tengely a szimmetria miatt páronként meröleges kell, hogy legyen egymásra, és 1 ponton kell, hogy menjen át. Emiatt a hatszögek egy kocka lapjain helyezkednek el, a 12 db ötszöglap a kocka 12 éléhez társítható, mert egy ötszöglap két olyan hatszöglapot köt össze, mely közös éllel rendelkező, szomszédos kockaoldalakon helyezkedik el. A hatszöglapok és ötszöglapok megszerkesztése után a háromszöglapok már automatikusan megszerkeszthetők, mivel a hatszöglapok és ötszöglapok lefogják az összes poliédercsúcsot. Adott élhosszú szabályos hatszögek és szabályos ötszögek esetén a kocka élhossza szerkesztendő - valamely két tengely által meghatározott síkot elmetszve a poliéderrel, egy Pitagorasz-tétel írható fel, melyet kifejtve az ismeretlen kockaélhossz egy másodfokú egyenlet gyöke lesz, és így megszerkeszthető lesz. Ez a poliéder 3. típusú ál-Johnson-poliéder, és csupán a háromszöglapjai között vannak nem szabályos sokszöglapjai. Ez egy ál-Johnson-poliéder $\varepsilon=0,018$ hibahatárnál közelebbi szabályos sokszöglapokkal, amelyek mindegyike látszólag szabályos.

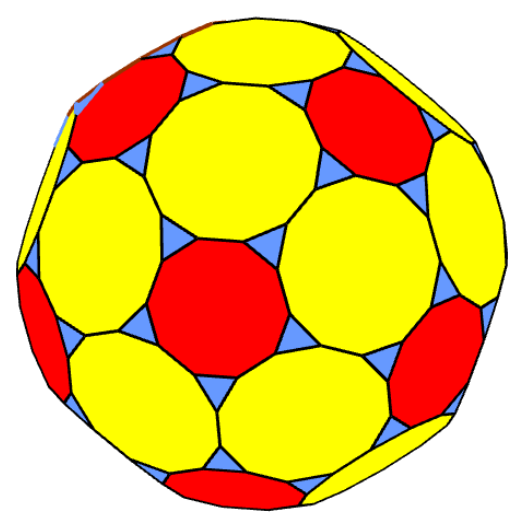

4. ábra. A 3. példa ál-Johnson-poliédere, a csonkolt csonka ikozaéder 
3. példa. Csonkolt csonka ikozaéder. A csonka ikozaédert (focilabdát) a csúcsainál egységesen szeljük, de nem tudjuk ugyanúgy szelni az ötszöglapoknál és a hatszöglapoknál: ha mondjuk szabályos 12-szöglapokat szeretnénk kapni a szelések után a hatszöglapokból, akkor az ötszöglapokból keletkező 10-szöglapok és a focilabda csúcsainál keletkező háromszöglapok sem lesznek szabályosak.

4. példa. Kifelé toljuk a csonka ikozaéder (focilabda) lapjait, a lapokra merőleges irányokban, egységes $s>0$ távolsággal az ötszöglapokat, és egységes $t>0$ távolsággal a hatszöglapokat. Ez egy kétparaméteres modellel megvalósítható, dinamikus geometriai szoftvert használva. Az eltolt lapokhoz csatlakozó téglalapokat és háromszöglapokat veszünk hozzá, hogy megkapjuk egy poliéder felületét (ld. 5. ábra). Az így adódó poliéder sok esetben konvex lesz, de bizonyos $s$ és $t$ értékekre konkáv poliéder adódik.

A hatszöglapok között elhelyezkedő négyszöglapok négyzetek lesznek $t$ megfelelö választása esetén. Az így keletkezett poliéder úgy is elkészíthető, hogy a focilabdánkkal azonos élhosszú, nagy rombikozidodekaéder nevü arkhimédészi test (amelynek csúcsaiban egy-egy szabályos 10-szög, 6-szög és 4-szög találkozik) mindegyik 10-szöglapjára olyan „sapkát” helyezünk, melyet poliéderünk egy ötszöglapja a vele határos téglalapokkal és háromszöglapokkal együtt alkot (ekkor a „sapka” alakja már csak az s paramétertöl függ). Ha most $s$ értékét úgy választjuk, hogy a hatszöglapokat az ötszöglapokkal összekötő négyszöglapok is négyzetek legyenek, a poliéder már nem lesz konvex (pedig ekkor még a háromszöglapok is szabályos sokszögek lesznek).

Olyan konvex poliédert, amely ál-Johnson-poliéder, úgy kaphatunk, hogy beállítjuk $t$ értékét arra a $t_{0}$ számra (vagy annak a közelébe), melyre a hatszöglapok közötti négyszöglapok négyzetek lesznek, ezután $s$ értékét pedig úgy állítjuk be, hogy a poliéder még épp konvex maradjon (de $s$ kismértékü növelésével már átváltson konkávba a poliéder alakja). Szerencsére ebben az esetben az ötszöglappal határos négyszöglapok és a háromszöglapok alakja is elég közeli a négyzethez, ill. szabályos háromszöghöz. Ez az ál-Johnson-poliéder nem 2. típusú, mivel van olyan csúcsa, amelyben a szögösszeg $360^{\circ}$ lenne, ha úgy számolunk az esetében, mintha minden lapja szabályos sokszöglap lenne.
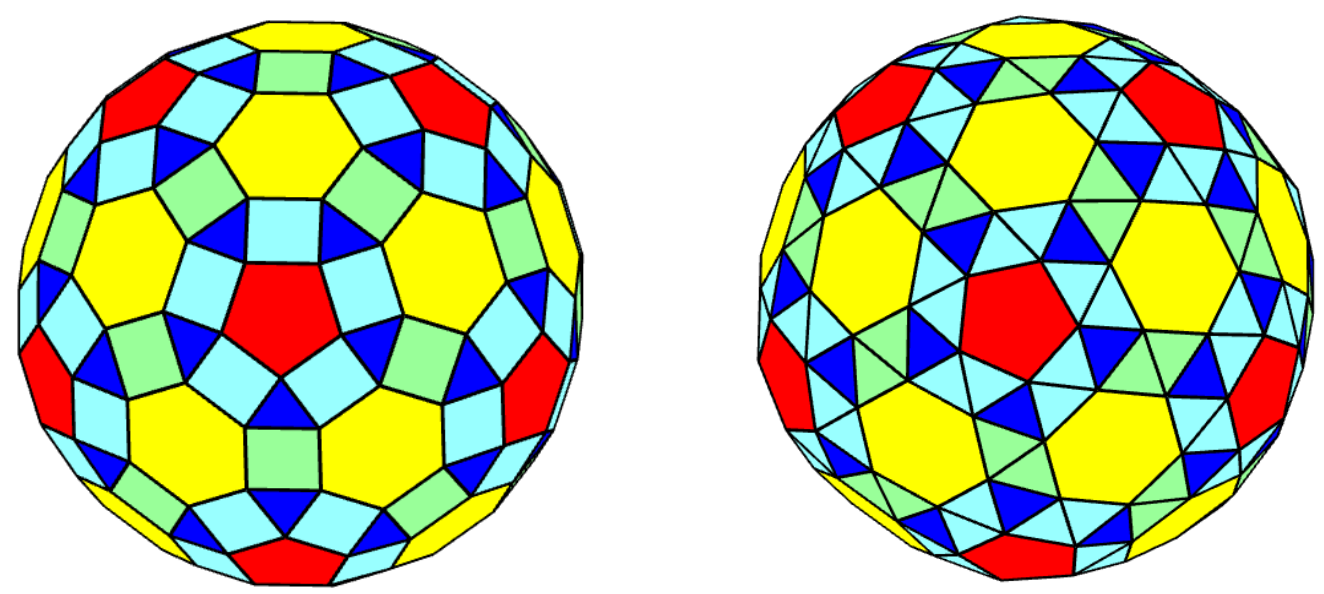

5. ábra. A 4. példa és 5. példa ál-Johnson-poliéderei

5. példa. Piszésítjük a csonka ikozaéder (focilabda) lapjait (kifelé toljuk azokat és egyben forgatjuk is őket a lapközéppontok és a testközéppont egyenesei, mint tengelyek körül, egységesen az ötszöglapokat és egységesen a hatszöglapokat is, és ezekhez a lapokhoz csatlakozó háromszöglapokat veszünk hozzá, hogy megkapjuk egy poliéder felületét (ld. 5. ábra). Az így adódó poliéder sok esetben konvex lesz, de bizonyos eltolásokra és 
forgatásokra konkáv poliéder adódik. A pisze dodekaéder 1-paraméteres poliédermodelljéhez hasonlóan (ld. [5]) adott forgatási szögre megszerkeszthetö, hogy a hatszöglapok hogyan legyenek eltolva, hogy közöttük egyenlő szárú háromszöglapok keletkezzenek (azaz, azok a háromszöglapok legyenek egyenlő szárúak, melyek csúcsait lefogják a hatszöglapok), majd beállítható úgy a forgatási szögük, hogy ezek a háromszöglapok szabályos háromszögek elég jó közelítései legyenek. Ezt követően be lehet úgy állítani az ötszögek eltolásait és forgatásait, hogy a velük szomszédos, újonnan keletkezö háromszöglapok alakja aránylag közel legyen a szabályos háromszöghöz, és még közben fennmaradjon a poliéder konvexitása is. Hasonlóan az elöző példához, itt is a konvexitás feltétele miatt áll fenn az, hogy az ötszöglapokkal szomszédos háromszöglapok alakja nem lehet akármilyen közel egy szabályos háromszöghöz.

Ez az ál-Johnson-poliéder nem 2. típusú, mivel van olyan csúcsa, amelyben a szögösszeg $360^{\circ}$ lenne, ha úgy számolunk az esetében, mintha minden lapja szabályos sokszöglap lenne.

\section{6. Összefoglaló}

Nincs még szisztematikusan feltérképezve az ál-Johnson-poliéderek családja. Többféle módszerrel lehet előállítani ilyen poliédereket, és ha elég nagyfokú a szimmetriája egy ilyen poliédernek, valamint elég sok szabályos sokszöglapja van, akkor az vagy szerkeszthető, vagy paraméteres poliédermodell felhasználásával elkészíthető a tetszőleges pontosságú közelítése.

\section{Köszönetnyilvánítás.}

Szeretném megköszönni Németh Lászlónak és Szalay Lászlónak, hogy erről a témakörről előadhattam Sopronban a Matematika Oktatása és Kutatása Szeminárium (MOKUS) 2021-es programjában.

\section{Irodalomjegyzék}

[1] Grünbaum, B., Johnson, N. W., The faces of a regular-faced polyhedron, J. of London Math. Soc. 40 (1965) 577-586. doi:10.1112/j1ms/s1-40.1.577

[2] Johnson, N. W., Convex Solids with Regular Faces, Canadian Journal of Mathematics. 18 (1966) 169-200. doi:10.4153/cjm-1966-021-8

[3] Near-miss Johnson solid, Wikipedia, https://en.wikipedia.org/wiki/Near-miss_Johnson_solid

[4] Talata, I., Gömbközelítések poliéderrel, Dimenziók IV (2016) 13-21. doi:10.20312/dim.2016.02

[5] Talata, I., Nemszerkeszthető Johnson-poliéderek számítógépes modellezése dinamikus geometriai módszerekkel, Dimenziók VIII (2020) 15-24. doi:10.20312/dim.2020.02

[6] Zalgaller, V. A., "Convex Polyhedra with Regular Faces". Zap. Nauchn. Semin. Leningr. Otd. Mat. Inst. Steklova (in Russian). 2 (1967), 1-221. 